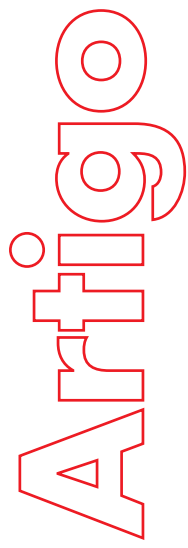

\title{
CENSUS POPULATION DATA AND REMOTE SENSING IMAGES \\ IN THE STUDY OF THE EVOLUTION OF THE SETTLEMENT OF CANABRAVA AND SURROUNDING AREAS, SALVADOR, BAHIA, BRAZIL, 1991 - 2010
}

\author{
Eudoxio Antonio Batista Junior \\ Patrícia Lustosa Brito \\ Anderson Dias de Freitas
}

p. $46-67$

revista

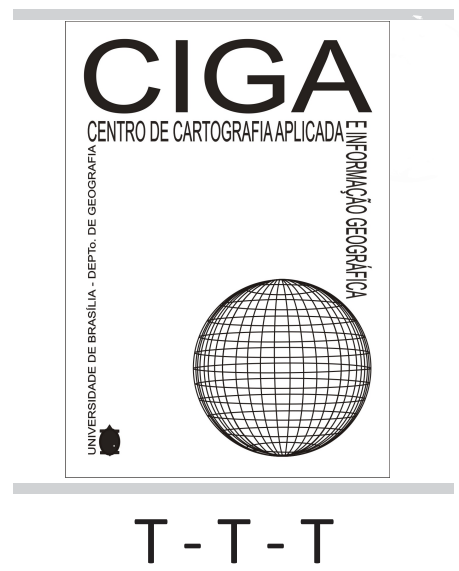

Eletronic Magazine:

Time - Techinique -Territorry, V.6, N.1 (2015), 46:67 ISSN: 2177-4366

DOI: https:// doi.org/10.26512/ ciga.v6i1.20920
Como citar este artigo:

BORGES, R. M. P. O. Cartography and territory of Araxá - MG: Past and Present. A Preliminary Reading and Interpretation. Revista Eletrônica: Tempo - Técnica - Território, v.6, n.1 (2015), p. 59:70 ISSN: 2177-4366. DOI: https://doi.org/10.26512/ciga.v6i1.20920

Disponível em: http://periodicos.unb.br/index.php/ciga/

Este obra está licenciado com uma Licença Creative Commons Atribuição-NãoComercial 4.0 Internacional. 


\title{
CENSUS POPULATION DATA AND REMOTE SENSING IMAGES IN THE STUDY OF THE EVOLUTION OF THE SETTLEMENT OF CANABRAVA AND SURROUNDING AREAS, SALVADOR, BAHIA, BRAZIL, 1991 - 2010
}

\author{
Eudoxio Antonio Batista Junior \\ Mestre em Engenharia Ambiental Urbana pela UFBA, Geógrafo do Ministério da Agricultura, \\ Pecuária e Abastecimento - Mapa \\ Email: eudoxioabjr@yahoo.com.br
}

\section{Patrícia Lustosa Brito}

Doutora na área de Informações Espaciais pela USP, Professora da Universidade Federal da Bahia UFBA

Email: patricia.brito@ufba.br

\author{
Anderson Dias de Freitas \\ Graduando em Engenharia de Agrimensura e Cartográfica pela UFBA \\ Email: anders.freitas@yahoo.com.br
}

\begin{abstract}
Urban sprawl in large Brazilian cities has intensified in recent decades, causing increased demand for urban infrastructure, urban services, and new areas for construction. The central goal of this article is to analyze the characteristics of urban expansion in the Canabrava community and its surroundings, in Salvador, Bahia, Brazil, using census data from 1991 and 2010 produced by the Brazilian Institute of Geography and Statistics (IBGE). One problem addressed was that the limits of the census tracts differed between the analyzed periods. To resolve this issue and enable a temporal analysis of the area studied, the methodology included the use of remote sensing images to adjust the boundaries of census tracts and to prepare charts, graphs, and tables of population growth and population and building density. These products showed the the dynamic of the area in relation to its population growth. Thus, the article contributes to a discussion of urban planning that aims to improve the population's quality of life, seeking to prioritize actions that meet new demands for infrastructure and urban services. In addition, the methodology proposed here demonstrates the feasibility of a study combining census tracts and remote sensing to accomplish these goals.
\end{abstract}


Keywords: urban sprawl, census tracts, remote sensing.

RESUMO: A expansão urbana vem ocorrendo de forma intensa nas últimas décadas nas grandes cidades brasileiras, ocasionando aumento da demanda por infraestrutura urbana, serviços e novas áreas para construção. O tema central deste artigo é analisar as características da expansão urbana na comunidade de Canabrava e seu entorno, em Salvador, Bahia, Brasil, com uso de dados censitários do IBGE dos anos de 1991 e 2010. Uma problemática tratada foi o fato de os limites dos setores censitários divergirem entre os períodos analisados. Como forma de propor uma solução para essa questão e possibilitar uma análise temporal do recorte da área estudada, a metodologia compreendeu o uso de imagens de sensoriamento remoto para o ajuste dos limites dos setores censitários e elaboração de mapas, gráficos e tabelas de crescimento populacional, densidade demográfica e edificações. Esses produtos evidenciaram a dinâmica da área em relação ao seu crescimento populacional. Com isso, o artigo contribui para discussões sobre um planejamento urbano que vise à melhoria da qualidade de vida da população, buscando priorizar ações que atendam demanda instalada e o incremento na demanda por infraestrutura e serviços urbanos. A metodologia aqui proposta mostra também que é viável o estudo combinado utilizando setores censitários e imagens de SR.

Palavras-chave: expansão urbana, setores censitários, sensoriamento remoto.

RESUMEN: La expansión urbana está ocurriendo con mayor intensidad en las últimas décadas en las grandes ciudades brasileñas, ocasionando una mayor demanda de infraestructura urbana, servicios y nuevas áreas para la construcción. El tema central de este artículo es analizar las características de la expansión urbana en la comunidad Canabrava y su entorno, en Salvador, Bahía, Brasil, utilizando los datos del censo del IBGE de 1991 y 2010. Uno de los problemas en la pesquisa fue que los límites de las secciones censales difieren entre los períodos analizados. Con el fin de proponer una solución a este problema y permitir un análisis temporal de la área de estudio, la metodología incluyó el uso de imágenes de sensores remotos para ajustar los límites de secciones censales y la preparación de mapas, gráficos y tablas de crecimiento poblacional, densidad de población y edificios. Estos productos mostraron la dinámica de la área de estudio relativa al crecimiento de su población. Así, el artículo contribuye a los debates sobre la planificación urbana dirigida a mejorar la calidad de vida de los habitantes, tratando de priorizar las acciones que satisfagan la actual demanda y el aumento de la demanda de infraestructura y servicios urbanos. La 
metodología propuesta también muestra que el estudio combinado utilizando secciones censales y las imágenes de teledetección es viable.

Palabras clave: expansión urbana, secciones de datos censales, teledetección.

\section{INTRODUCTION}

The expansion of urban areas, especially of residential condominiums, has been occurring intensively over the last decades in large Brazilian cities, increasing the demand for urban infrastructure, urban services, and new areas for buildings and other construction. Concomitant to this process, expansion and densification of informal settlements has occurred, causing an increase in the demand for infrastructure and urban services. This situation has reduced the area of vegetation and generated the rise of social inequalities in the inner urban space because older communities installed precariously generally do not benefit from the improvements and better conditions of urban infrastructure provided by the real estate expansion.

The study area is located in a central part of Salvador (Bahia State, Brazil), in a region known as the "core" of the city, as shown in Figure 1. This area is limited at its southern edge by the Luís Viana Filho Avenue (known as Parallel Avenue), which is considered to be the most recent site of real estate expansion in the city. Because of this proximity, the land is attractive to the real estate market, which exerts strong pressure to incorporate these areas. To the north, the studied area is limited by Aliomar Baleeiro Avenue, which is known as Old Airport Road because it connected the city to the airport before Parallel Avenue was constructed. To the east, the area is limited by the Mocambo river valley (Trobogy river tributary), and to the west it is influenced by the Artêmio Castro Valente and Proc. Nelson Castro streets, principal roads that cross this area.

The studied area had, as initial core of settlement, the community of Canabrava, which originated in the 1970s following the relocation of populations from other areas of the city, in virtue of the construction of new roads and in consequence of heavy rains. This community also originated from spontaneous settlement by people who came for the sorting and collecting of trash, since at that time it was in this area of the city that all city garbage was deposited without any treatment. The inappropriate garbage dump site was deactivated in 1998 and became a controlled landfill (Figure 2), resulting in a loss of means of livelihood for many area residents and thereby aggravating the area's social problems (PANGEA, 2010). 


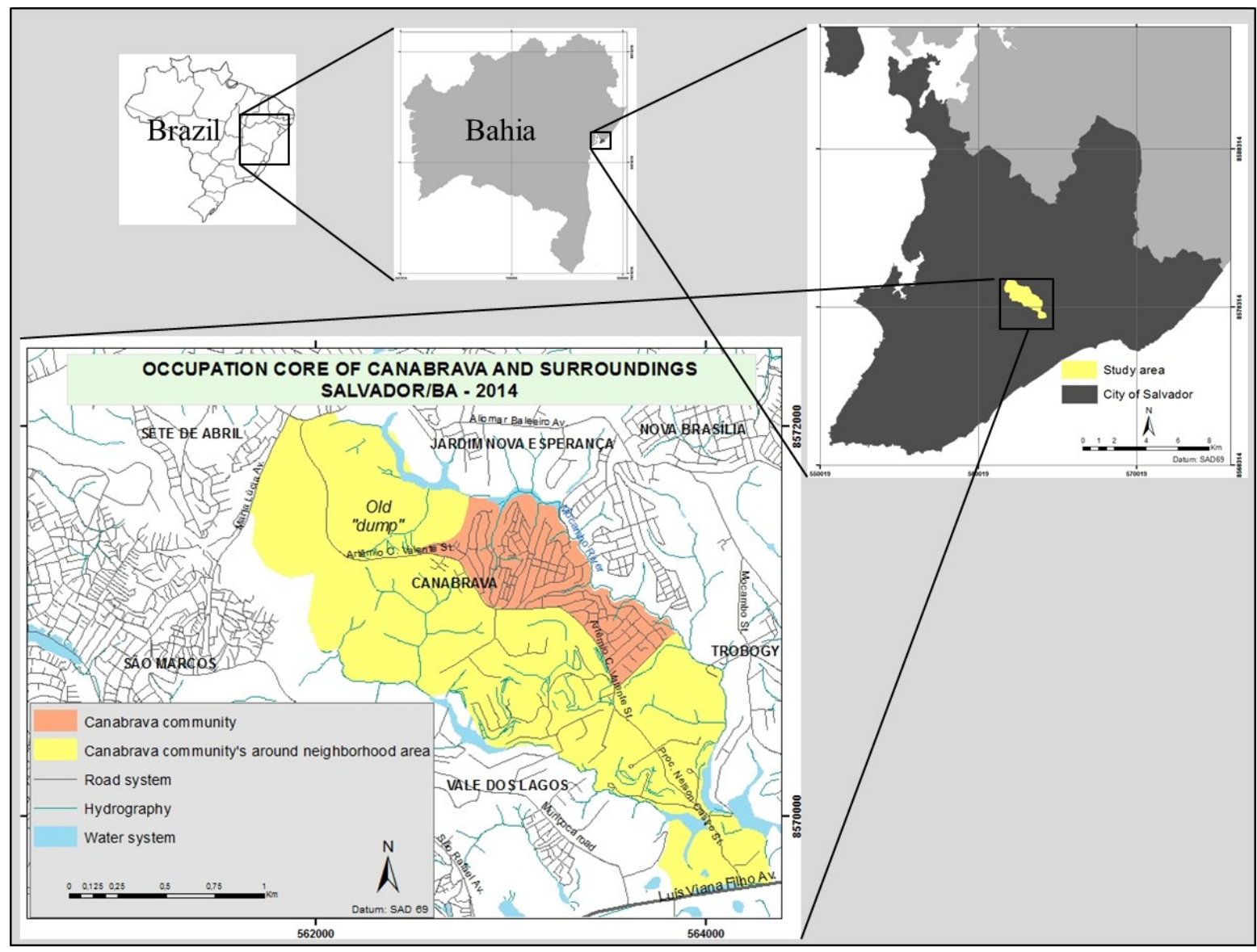

Fig. 1 Study area

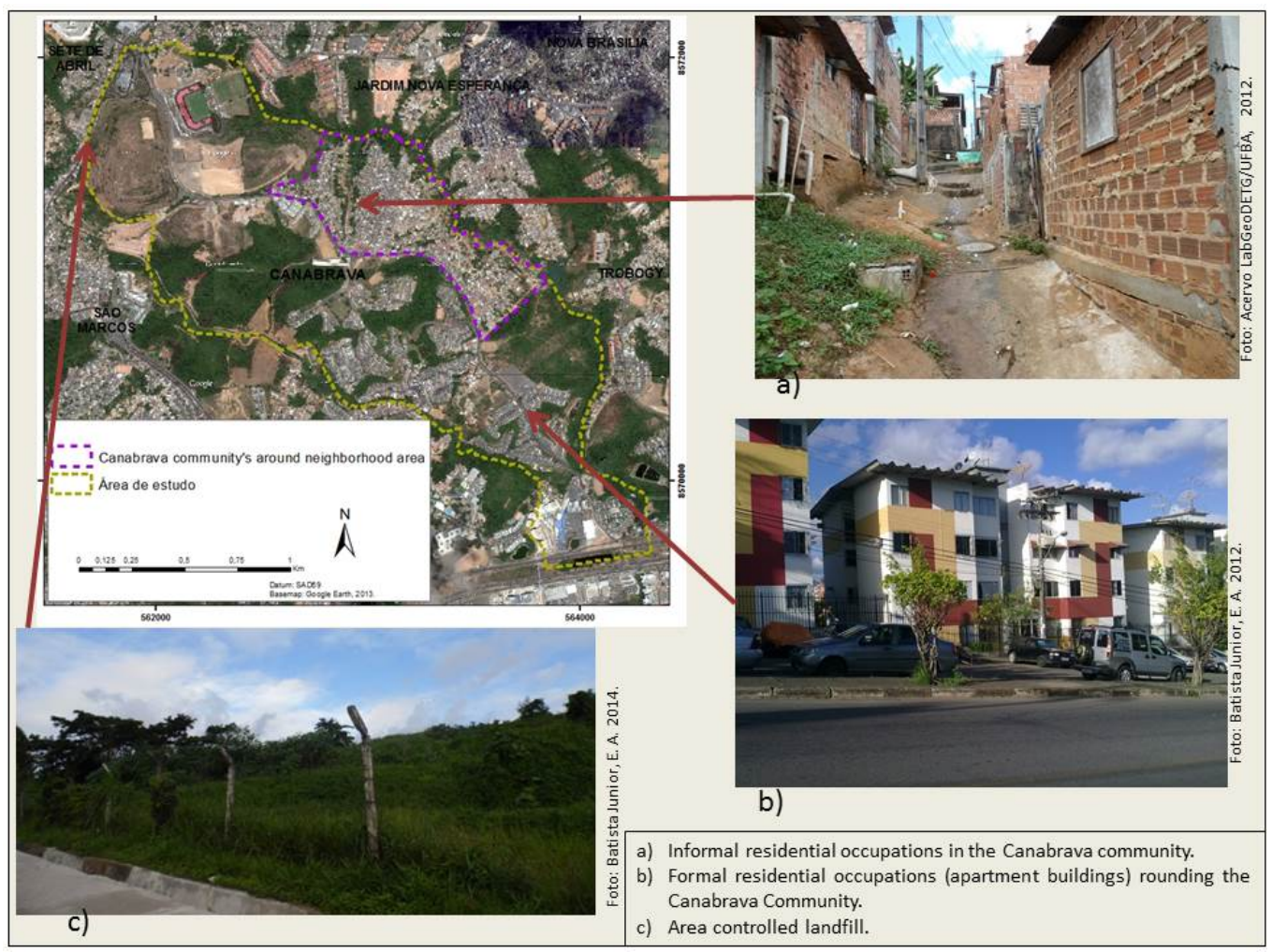


Fig. 2 Different settlement patterns in the study area

The principal sources of data for the study of this demographic evolution are the IBGE censuses, which have the census tracts as their smallest unit of spatial aggregation and available information. The IBGE's census tracts often do not keep the same configuration over the years, a fact that was verified in the studied area. This makes a comparative analysis on a temporal scale more difficult. In addition, IBGE's boundaries do not coincide with the defined area of study. Remote Sensing images can prove to be an efficient tool to solve this problem and this article uses, in a combined form, the census data and the remote sensing images to enable this study in a temporal scale.

Proceeding from a literature review on the subject of urban expansion and with the objective of better understanding this topic, it is possible to consider three related macro-factors: expansion in the city proper (horizontal expansion), occupation density, and existence and quality of urban infrastructure as a whole. Horizontal expansion involves three components: formal city growth, informal growth, and the characteristics of land use and residency over time. The growth of the formal city, known as the legal city, occurs when the constructions and occupations of the space are made on land whose ownership is legalized. In this context, at one side exists the person who finances the construction of his own home and, on the other, the real estate market with residential and commercial ventures. In these cases, it is important that the basic urban infrastructure that makes possible the existence of residences and the development of productive activity in that area, such as a sanitary sewage system and an electric power network, either exist a priori or be developed. Normally, these systems are provided by the public management before the construction of the houses and real estate developments. In contrast, the informal city growth occurs at the margins of this infrastructure.

In general, the more a city expands, the more dense it becomes, with an ever increasing number of living spaces constructed. In this way, the rise of city density involves three processes: verticalization, increase of built area, and population growth. The increase of population density is directly related to population growth and verticalization. The population growth causes an increase in the number of inhabitants on the municipal territory that, as a rule, remains the same, causing the population density and the built area to increase. It is common, in bigger urban centers, for this process to culminate in city verticalization, with an ever more numerous construction of tall buildings, as a way of better harnessing urban land in response to the ever increasing scarcity of available areas for construction. There are various aspects that determine the rhythm and form of 
this verticalization such as the land value, financial agents involviment, actions of the companies in the real estate market, directives of city statutes, and the social, economic, and environmental impacts arising from the enterprises.

Urban infrastructure is one of the most important components of urban expansion. This is because urban infrastructure involves services and equipment essential to meeting the demands of life of a particular population, making a direct influence on the quality of life. The infrastructure makes possible the use of urban space, as Mascaró (2005) states, being an element that associates form, function and structure in the same space. The urban infrastructure, in a general sense, covers the following elements: paths of circulation of people and vehicles, sanitation systems (water supplies, sewage systems, drainage, and urban cleaning), electric power systems, communications networks, and the infrastructure of public spaces for leisure, sports and culture. There are services directly connected to the urban infrastructure, such as all of the diverse modalities of transport systems, education, health and public security. Urban infrastructure is directly related to public policies and to urban expansion. Urban expansion is a result of the articulations of the real estate market with the public policies that ensure the necessary infrastructure to its expansion, according to Souza (2005). Therefore, studies involving urban expansion should consider the role of public policies in urban environment over time, showing how the population of a city is treated in regards to its daily demands for equipment and urban services. In this sense, real estate capital has a strong influence that acts to impact, to a lesser or greater degree, urban public policies.

Outside the areas of real estate capital investment, the growth of the informal city is carried out by the settlement of idle lands by the neediest population, with construction of houses being completed by the people themselves without any technical support. The informality in urban settlement, according to Gordilho-Souza (2008), refers to the conformation of areas outside the formal standards set out for residential areas, with disregard for the established urban codes and standards. These are the so-called informal settlements, and can be of many different types, such as stilts, masonry, or wooden houses. These settlements, also called "invasões" (invasions), normally exist in areas with precarious urban infrastructure or without any infrastructure at all. Maricato (2011) uses the term precarious housing, which according to the author is more accurate than the term urban periphery, because it refers to the generalized situation of illegality and precariousness of housing that does not occupy only the urban periphery.

In the current form in which urban expansion in Brazil is occurring, the invasions usually happen around or on the periphery of neighborhoods with good urban infrastructure, taking 
advantage of the proximity of the so-called "formal city" as a solution to mobility problems. The situation is more critical when these invasions occupy the urban periphery, located far from the centers of the city's economic activities and causing a demand for public transportation for its residents that is often not answered or, if it is, is not answered in a satisfactory way. In both cases, the quality of life of the population of this informal city is seriously affected, requiring public policies to solve or minimize its daily problems.

This article proposes the use of remote sensing images, which is a set of processes and techniques used to measure electromagnetic properties of a surface or an object without contact between the object and the sensor equipment (CAMERA, 1996). The majority of sensors have certain properties in common such as spectral resolution, radiometric resolution, spatial resolution, and temporal resolution (NOVO, 2008). Spatial resolution is the property that defines the ability of the sensor to detect the minimum object to map.

Remote sense images can be aerial photographs (obtained by a sensor installed on an airplane) or orbital images (obtained by a sensor installed on a satellite). Aerial photographs can be vertical or oblique. Vertical aerial photographs present the optical axis of the camera as vertically as possible (ROSA, 2007) and are corrected geometrically (x and y axis), becoming ortho-photographs (JENSEN, 2009). Vertical images taken by sensors aboard orbital satellites can reach extremely high spatial resolutions, as exemplified by the images of large urban centers, like Salvador, published on Google Earth, allowing the identification of urban targets such as buildings, streets, and even sidewalks.

Remote sensing is being increasingly used in studies monitoring urban growth. Almeida et al. (2006), for example, present a description of the application of the digital processing of satellite images in urban studies in Brazil since the 1970s. This research shows that, with advances in the spatial resolutions in the order of $0,67 \mathrm{~m}$ to $1 \mathrm{~m}$ in the panchromatic band and $4 \mathrm{~m}$ in multispectral bands the new generation of orbital sensor represents a revolution in terms of image processing methods, as well as in the level of detail of the urban scenario, enabling promising forms for the exploration of the inner urban universe and expanding the horizons of Remote Sensing applications for physical-environmental and territorial plannings. In the current scenario, the high resolution images are indispensable for monitoring changes in urban land use, as claim Leite et al. (2014), and, as it can be seen the historical series of orbital, remote sensing products can reveal the dynamics of the city in a temporal frame. 
Lombardo (1996) noted that GIS allowed the full use of remote sensing in focusing on the urban reality, making possible temporal monitoring compatible with the speed of the changes that occur in large cities. In this way, it is possible to verify that there are many possibilities for remote sensing applications in studies of the various phenomena that occur in the urban environment. This is shown by the research conducted by Martins and Leite (2015), which examined the growth of slums, and the research produced by Brito (2010), which investigated urban patterns associated with the occurrence of leptospirosis. Both researchers used higher spatial resolution images and GIS. There are more studies, such as the work realized by Volpe and Lombardo (2011), which used aerial photos and high resolution images from IKONOS satellite to examine the temporal dynamics of land use on the edge of a road axis in the city of São Paulo.

\section{OBJECTIVES AND METHODOLOGY}

This article aims to study the characteristics of urban expansion in the community of Canabrava and the surrounding area by using IBGE demographic census data from 1991 and 2010 and remote sensing images from 1992 and 2013. The main objective is to provide a hybrid method combining images of remote sensing and census data in order to extract quantitative and qualitative information about the urban evolution of the area between the years of 1991 and 2013. Ultimately, the intention is to analyze population growth through the study of growth rates and population density.

This type of study is justified by its contribution to discussions that seek to develop effective urban planning that proposes alternatives allowing for improvements in the population's quality of life as a whole. Knowledge of demographic characteristics for the defined portion of the city provides the necessary background for the adjusted prioritization of actions that meet the existing and increasing demand for infrastructure and urban services. Similarly, in proposing a methodology for joint use of census data with remote sensing images, this study becomes a reference for methodological works that aim to carry out this same joint use, providing a possible solution to work around certain inconsistencies, such as the differences between boundary census sectors over the years.

This study proceeded from bibliographical and documentational research about the study area and its demographic characteristics. The consultation of bibliographical material was made in the network libraries of the Polytechnic School, the school of Architecture and Urbanism, and the 
Geoscience Institute of the Federal University of Bahia (UFBA), through the internet pages of public universities, through the CAPES and Scielo periodicals portal, and through the sites of public and private institutions that have information about the study area such as CONDER, IBGE, and PANGEA. Base mapping data of Salvador city available from CONDER were used, with reference to the 1992 version, in 1:2.000 scale, and the 2012 version, with edits and updates of the road system made by the research team from LabGeo/DETG/UFBA in 2012. The data used from this source institution were hydrography - composed of information on rivers, bodies of water, and road systems.

The geographical boundaries of the census sectors of 1991 and 2010 were obtained from the IBGE database, on its internet page, in "shapefile" format. The statistical data provided by IBGE for the census in question were also obtained in table format from the same institution internet page.

Remote sense images were obtained from two sources. Namely, the 1992 image is a mosaic of panchromatic aerial photos in 1:10.000 scale provided by CONDER, and the 2013 image was obtained by the georeferencing of a mosaic of images mounted from higher resolution images published on Google Earth.

The delimitation of the study area was based on the road influence related to the study area. The boundaries of this area were set on top of the neighborhood boundaries considered by Santos et al. (2010) in the publication "O Caminho das Águas em Salvador" (The Paths of the Waters in Salvador). The study considered the areas influencing the two main routes that cross the neighbourhood, Artêmio Castro Valente and Proc. Nelson Castro streets, which serve as a link between the Aliomar Baleeiro Avenue (known as the old road to the airport, for being the former axis of connection to the Salvador airport) and Luis Viana Filho Avenue (known as Parallel Avenue). The eastern portion of the Canabrava community corresponds to the "Jardim Nova Esperança," “Nova Brasilia,” and “Trobogy” neighborhoods, as a result of not having a socioeconomic interaction or traffic with the area, because the inset configuration - being the divider of these areas of the Mocambo river valley, and also the fact of there being no traffic routes linking Canabrava to these areas and, therefore, no contiguous traffic - was not considered within the studied area.

Proceeding from the researched material, the methodological procedures were executed, whose general flowchart can be seen in the Figure 3. 


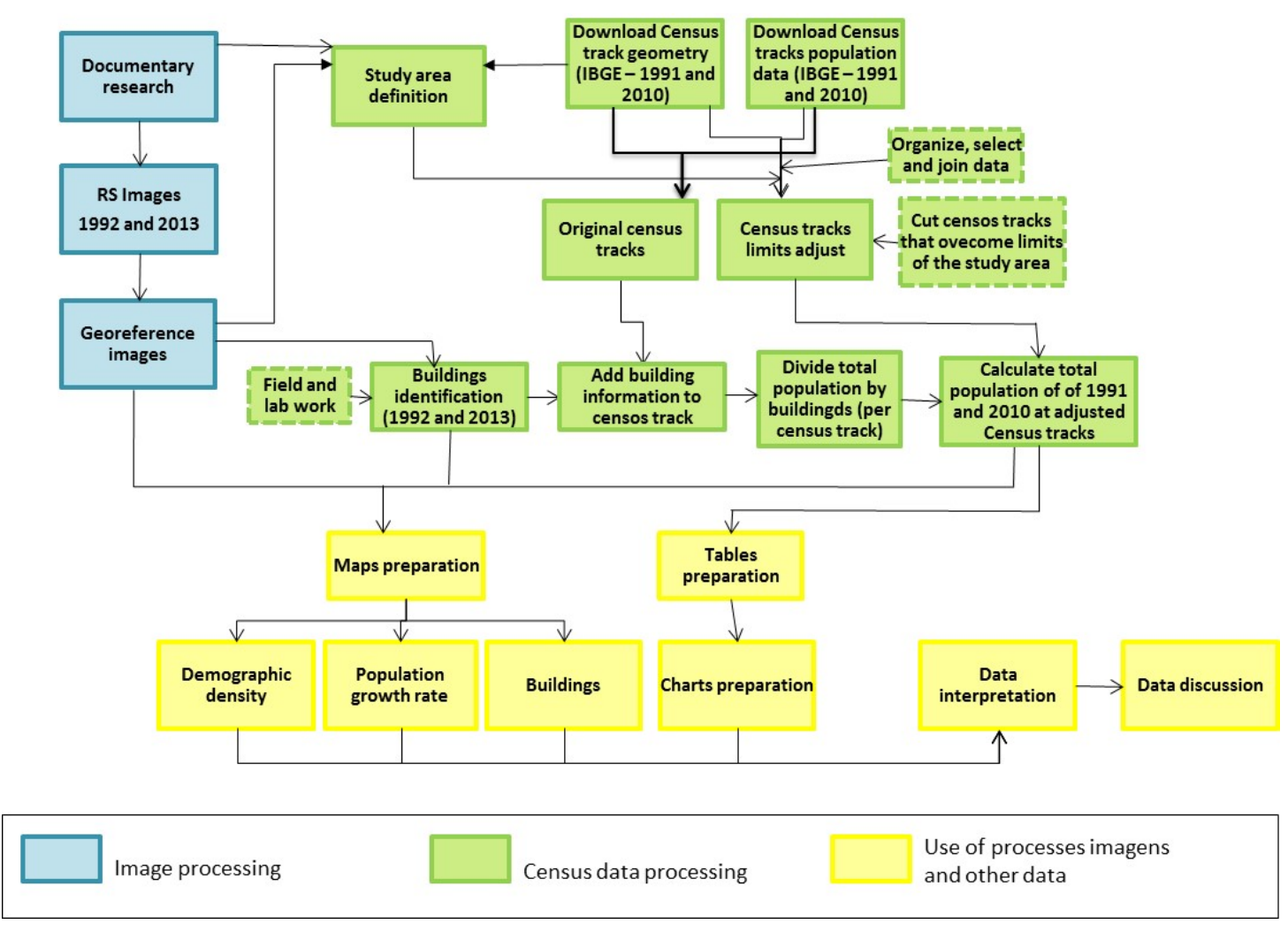

Fig. 3 Methodological procedures flowchart

The steps developed in the methodology were as follow:

1- Georeferencing of images with the software Quantum GIS version 1.8.0;

2- Processing of the census data with cutouts of the census sectors comprising the study area, as illustrated in Figure 4;

3- Processing of the data for the preparation of tables and charts with the increase of population, buildings, and population density;

4- Preparation of maps with the population density and with the population and building growth rate;

5- Interpretation of the data and discussion of the results. 


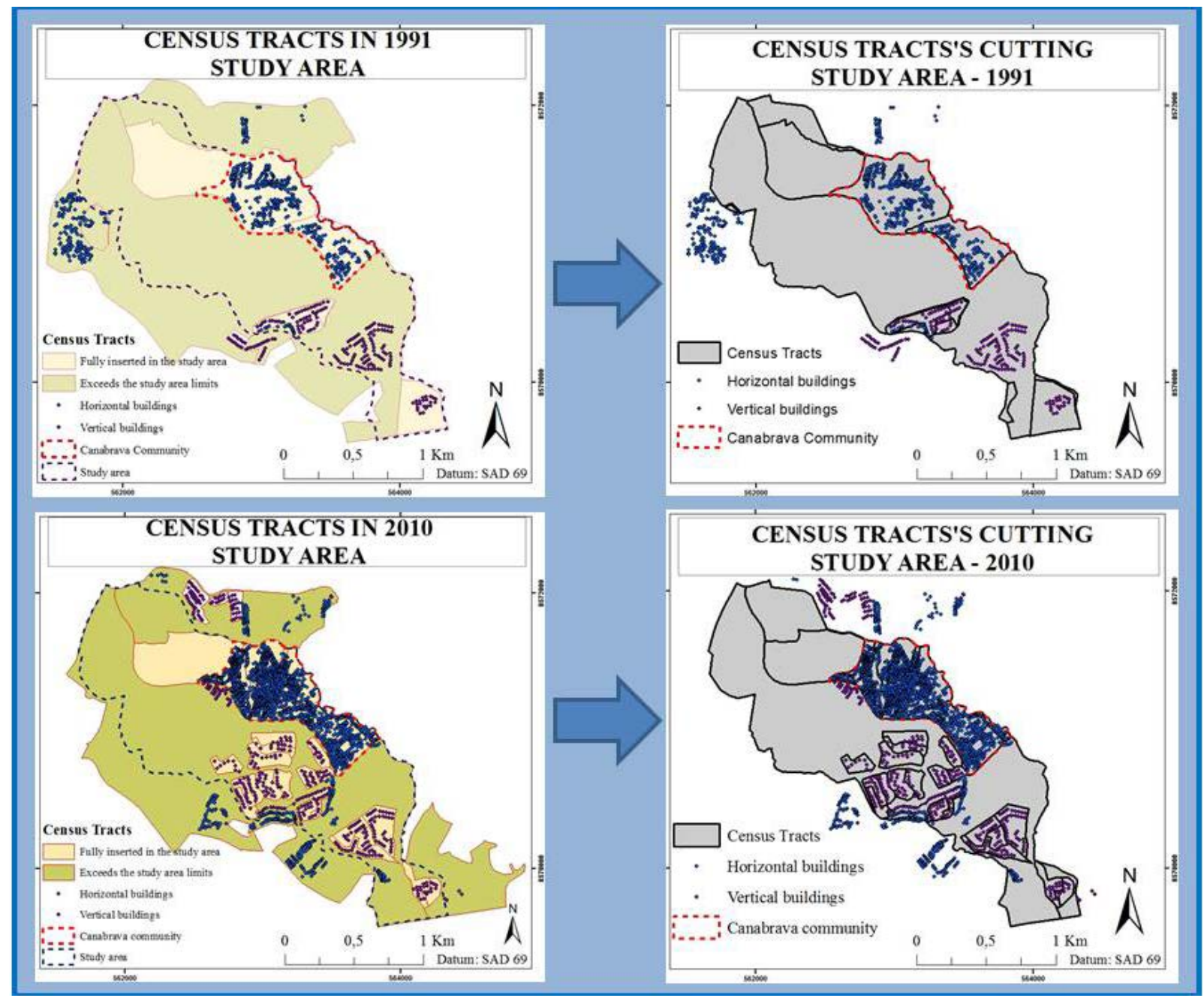

Fig. 4 Census tracts adjustment procedures

The census tracts from 1991 and 2010 match neither in respect to their number nor in respect to their limits. Because of this, adjustments were made with the use of the vertical images closest to the years of census data available (1991 and 2010), so images from 1992 and 2013 were used. Thus, the second step described in the list above and illustrated in Figure 4 was the most complex and involved the following phases:

a) Identification and selection of the census sectors that covered the area of study;

b) Marking a point feature for each buildings (vertical or horizontal) present in the selected tracts, from the images of 1992 and 2013. The vertical buildings was checked in field, for 2013 data, and the number of apartments and floors was counted, to estimate the total of households in each building, through the "Street View” from Google Earth; 
c) Calculating how each household corresponded to the population by dividing the total population counted in the census sector by the number of households inside it;

d) Clipping the tracts that cross the boundaries of the study area, estimating the new population census tract's value based on the number of households present in the clipped part of the tract, inside of the study area; this number was calculated based on the number of existing vertical buildings, considering the number of floors and apartments per floor; multiplying the number of households by the medium value of inhabitants to obtain the total population of each tract;

e) Recalculating the area (in hectares) of the clipped tracts;

f) Calculating the population density of the new clipped tracts from the estimated calculated population and the new area;

g) Overlapping the households with their average number of people in 1991 with the sectors in 2010, in order to know, for each tract from 2010, what the corresponding number of people/population in 1991 was;

h) Calculating the growth rate based on 2010 tracts, with use of the data from 1991 overlaid on each tract.

\section{RESULTS AND DISCUSSION}

The processing of data obtained by combining remote sensing images with the census tracts made possible the knowledge of the rate of population growth and density in the study area. When analyzing the total population data, as shown in Table 1, it can be seen that while the community had an increase of $80.68 \%$ from 1991 to 2010, its surroundings had a much higher increase in the same period, which was $181.73 \%$. These percentages, as well as the population growth of the whole study area (133.95\%) are higher than the rate of the city of Salvador in the same period, which was 29.04\%, reaching 2,675,656 inhabitants in 2010, according to IBGE. The pace of total population evolution in the community and surroundings can be seen in Figure 5.

Table 1 Population data of Canabrava and surroundings 1991 - 2010

\begin{tabular}{|c|c|c|r|r|r|r|r|}
\hline & \multicolumn{2}{|c|}{ Total Population } & \multicolumn{1}{c|}{$\begin{array}{r}\text { Increase 1991-2010 } \\
\text { (No. total) }\end{array}$} & $\begin{array}{c}\text { Increase 1991-2010 } \\
\text { (em \%) }\end{array}$ & $\begin{array}{c}\text { AREA } \\
\text { (ha) }\end{array}$ & $\begin{array}{c}\text { Demographic Density } \\
\text { (population/ha) }\end{array}$ \\
\hline & $\mathbf{1 9 9 1}$ & $\mathbf{2 0 1 0}$ & $\mathbf{1 9 9 1}$ & $\mathbf{2 0 1 0}$ \\
\hline Canabrava Community & 4.266 & 7.708 & 3.442 & 80,68 & 45,58 & 93,60 & 169,12 \\
\hline $\begin{array}{c}\text { Canabrava community's } \\
\text { surrounding area }\end{array}$ & 4.756 & 13.399 & 8.643 & 181,73 & 226,53 & 21,00 & 59,15 \\
\hline \begin{tabular}{c} 
Study area \\
\hline
\end{tabular} & 9.022 & 21.107 & 12.085 & 133,95 & 272,10 & 33,16 & 77,57 \\
\hline
\end{tabular}




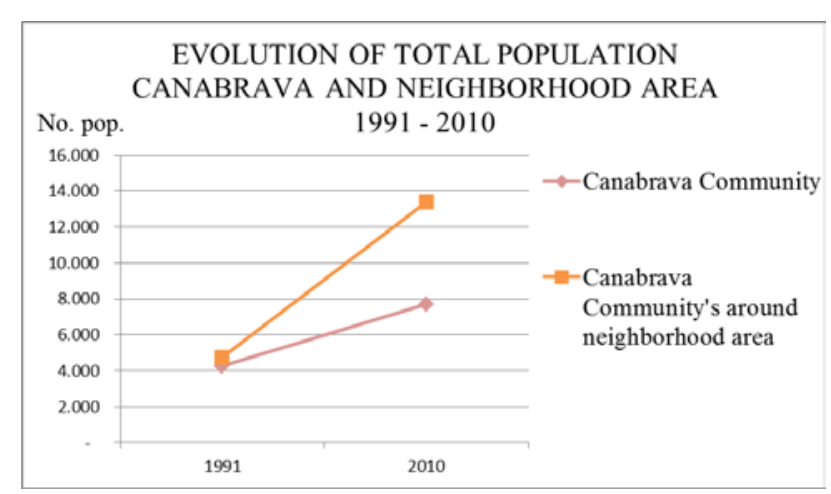

Fig. 5 Evolution of total population in Canabrava and surroundings 1991 - 2010

The number of buildings in the study area has increased considerably, as can be seen in table 2. However, there is a different standard between the community and its surroundings. In the first there are only horizontal buildings (houses), a consequence of its occupational characteristics. On the other hand, in the surrounding area there is a predominance of vertical buildings, a consequence of the advancement of residential condominiums in the area. These characteristics remained the same from 1991 to 2010, and it is important to emphasize that there was a large increase in the number of buildings in the area as a whole. Building distribution, in 1991 and 2010, can be viewed respectively in figures 6 and 7.

Table 2 Buildings in the study area

\begin{tabular}{|c|c|c|c|c|c|c|c|c|}
\hline \multirow{2}{*}{ Area } & \multicolumn{2}{|c|}{1991} & \multicolumn{2}{c|}{$\mathbf{2 0 1 0}$} & \multicolumn{2}{c|}{$\begin{array}{c}\text { Increase 1991-2010 } \\
\text { (No. total) }\end{array}$} & $\begin{array}{c}\text { Increase 1991-2010 } \\
\text { (\%) }\end{array}$ \\
\cline { 2 - 9 } & $\begin{array}{c}\text { Horizontal } \\
\text { buildings }\end{array}$ & $\begin{array}{c}\text { Vertical } \\
\text { buildings }\end{array}$ & $\begin{array}{c}\text { Horizontal } \\
\text { buildings }\end{array}$ & $\begin{array}{c}\text { Vertical } \\
\text { buildings }\end{array}$ & $\begin{array}{c}\text { Horizontal } \\
\text { buildings }\end{array}$ & $\begin{array}{c}\text { Vertical } \\
\text { buildings }\end{array}$ & $\begin{array}{c}\text { Horizontal } \\
\text { buildings }\end{array}$ & $\begin{array}{c}\text { Vertical } \\
\text { buildings }\end{array}$ \\
\hline Canabrava community & 429 & 0 & 1700 & 0 & 1271 & 0 & 296,27 & 0 \\
\hline $\begin{array}{c}\text { Canabrava community's } \\
\text { surrounding area }\end{array}$ & 20 & 153 & 108 & 317 & 88 & 164 & 440,00 & 107,19 \\
\hline Study area & 449 & 153 & 1808 & 317 & 1359 & 164 & 302,67 & 107,19 \\
\hline
\end{tabular}




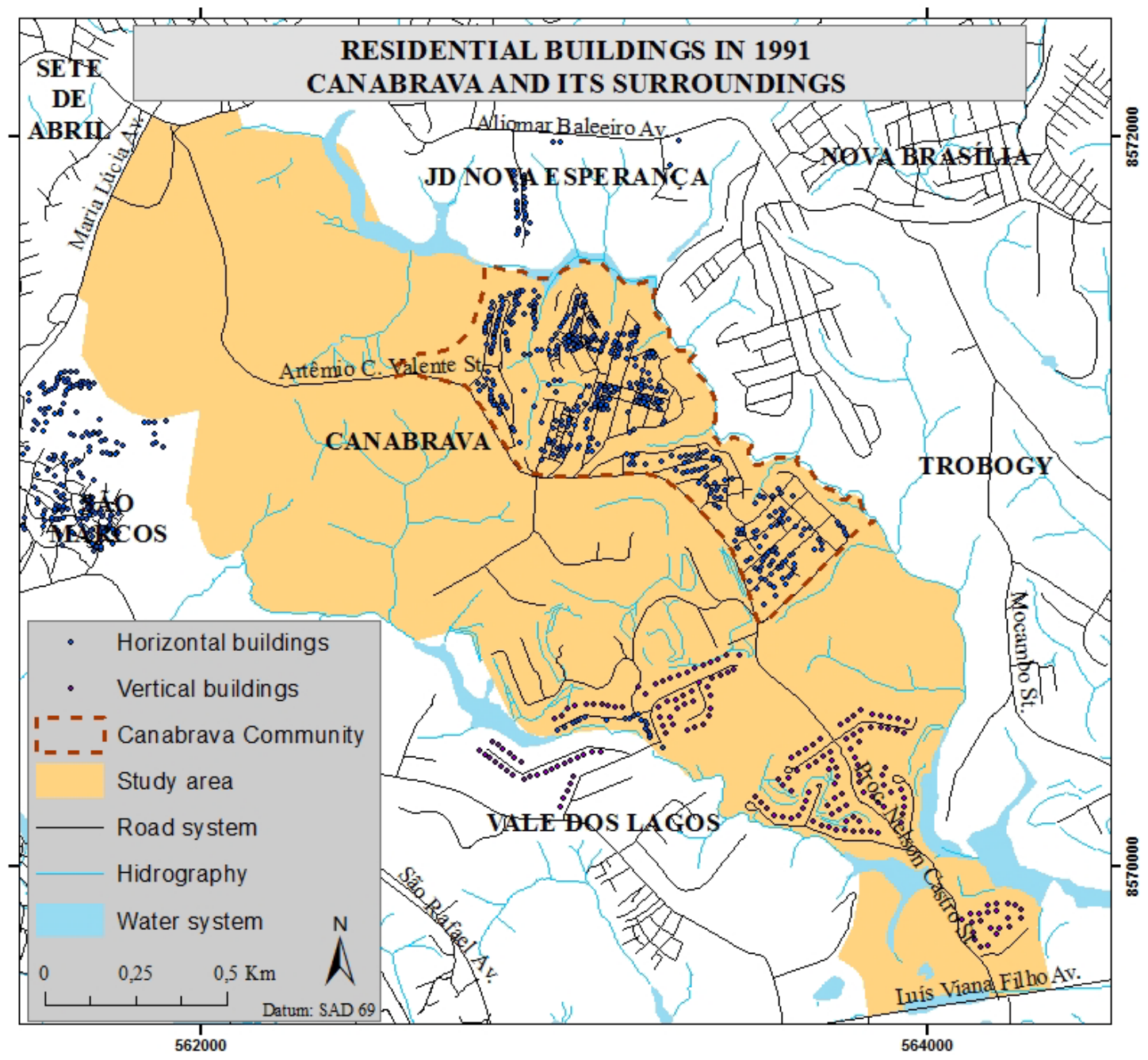

Fig. 6 Residential buildings in the study area in 1991 


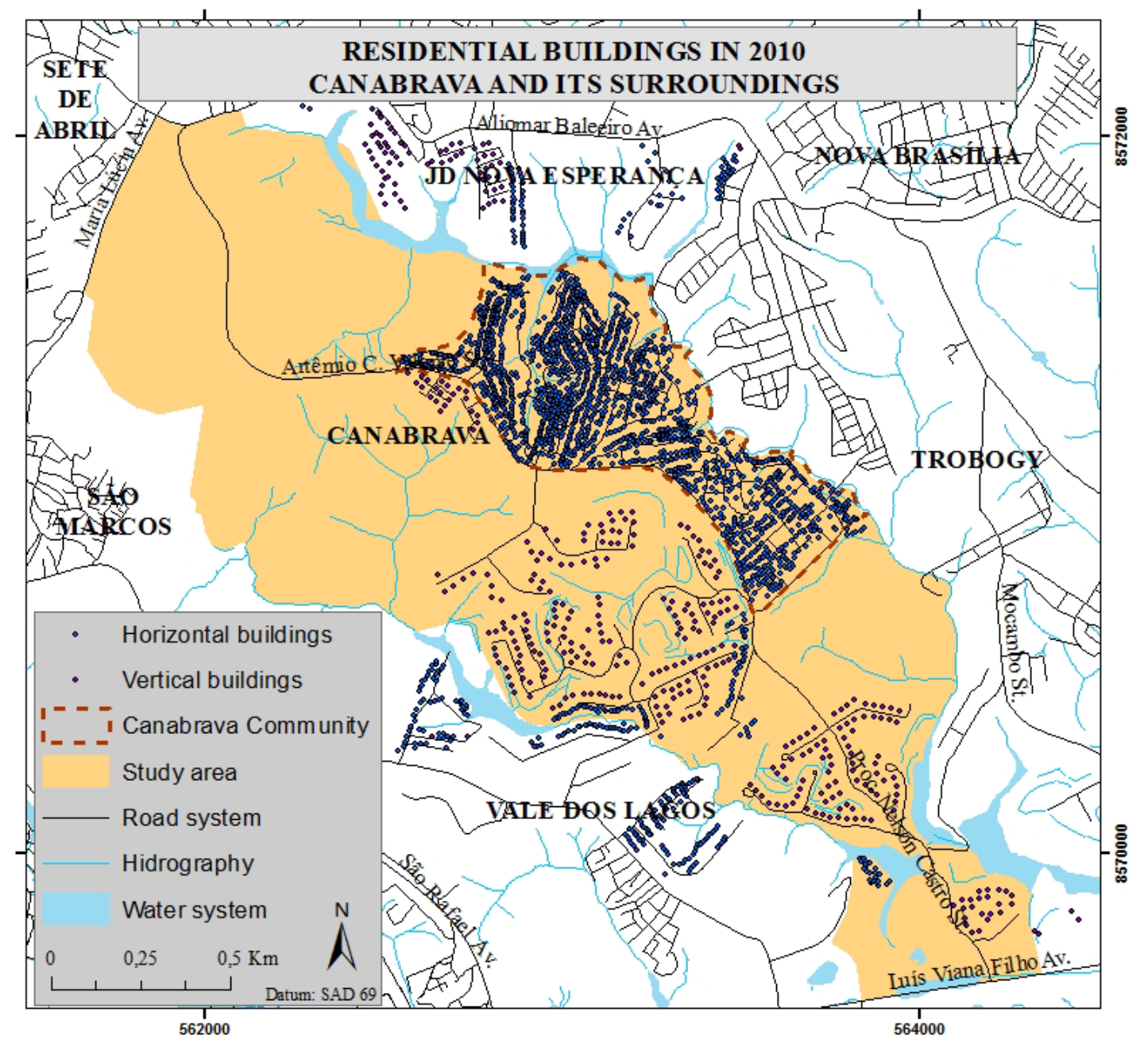

Fig. 7 Residential buildings in the study area in 2010

The data on buildings and population of the study area demonstrate the high population density that occurred. The demographic density increased as a whole in the community and in its surroundings, as can be seen in Figure 8.

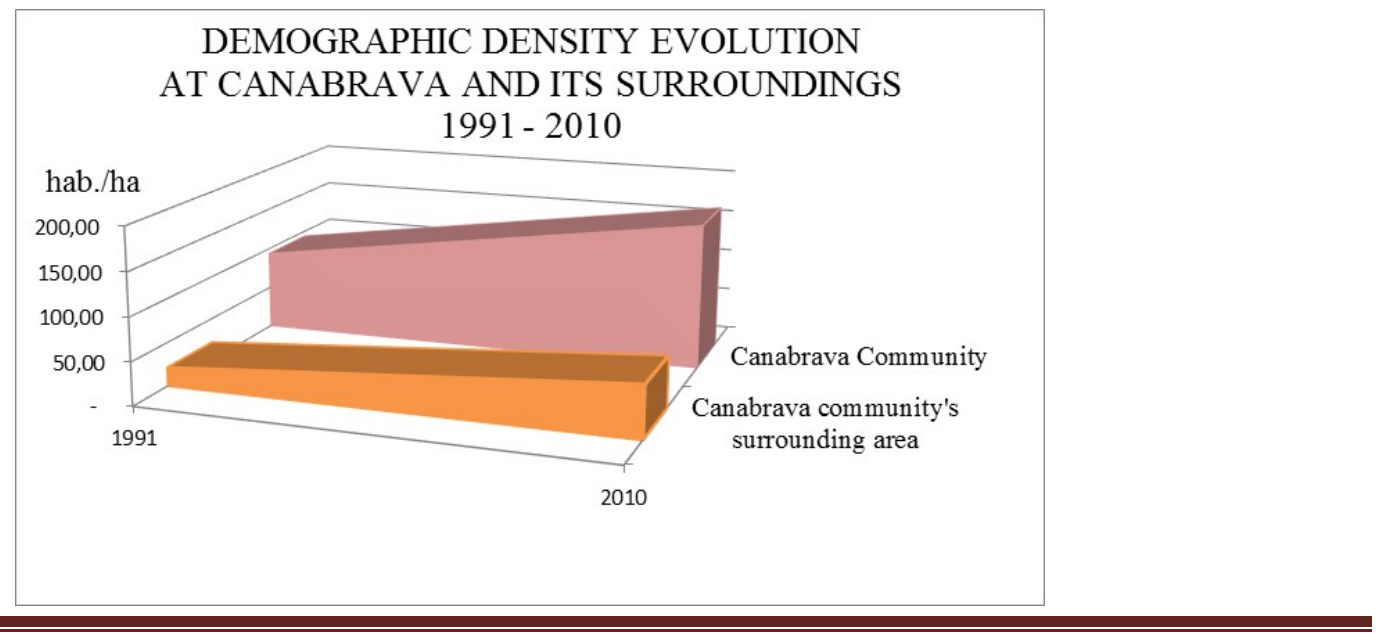


Fig. 8 Demographic density evolution graph, from 1991 to 2010, of the study area

The comparison between demographic density maps in 1991 and 2010, shown respectively in Figure 9 images a) and b), allows for comprehension of how much area was thickened in specific locations in the area surrounding Canabrava community. The areas where there are residential condominiums saw the greatest increase in density in the study area, as can be seen by crossing these images with the building map, shown in Figure 7. Because it is a relatively large area, the environment still remains with many "urban voids". The same situation did not occur inside the community, which presented a great population density.

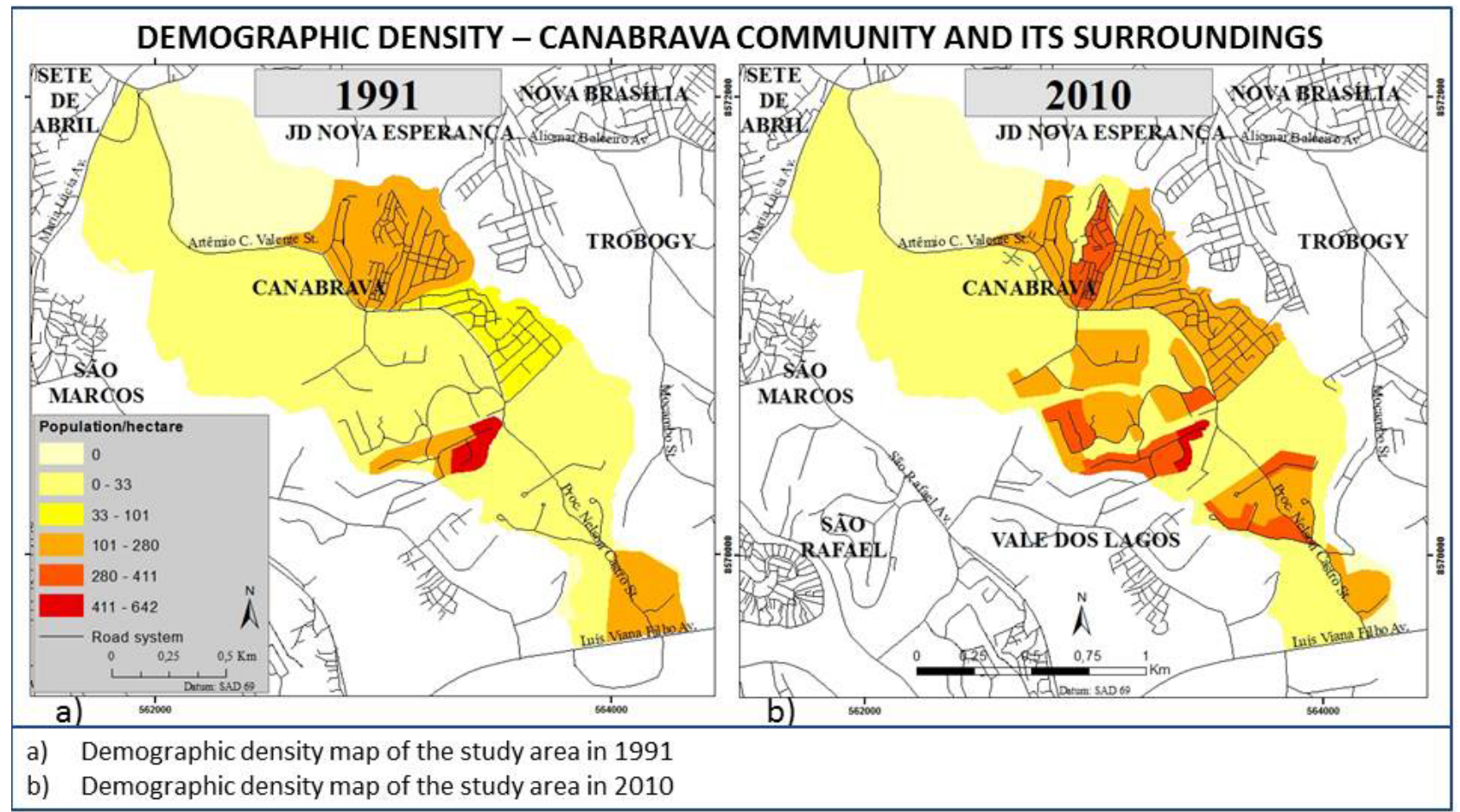

Fig. 9 Demographic density map of the study area in 1991 and 2010

The crossing between the census tracts of 1991 and 2010 makes it possible to check what areas had the most population growth, as can be seen in Figure 10. It is observed that there was an increase from 0 to 100 inhabitants per hectare in most of the study area in this period. There was an increase of 200 to 300 inhabitants per hectare in a large part of the community's area. The largest increments of inhabitants (300-400 pop./ha) occurred in areas occupied by residential condominiums in the area surrounding the community. 


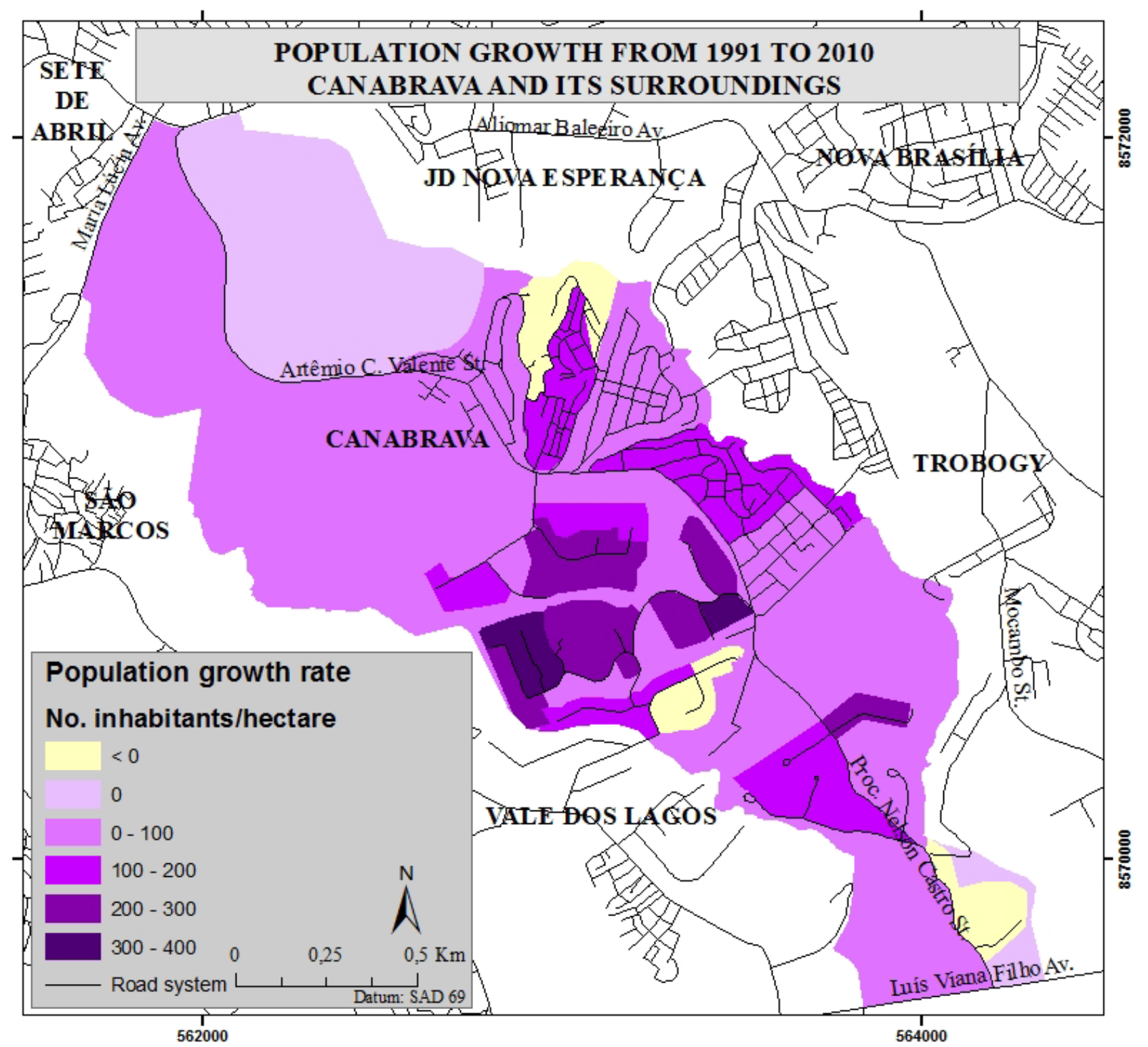

Fig. 10 Population growth from 1991 to 2010 map of the study area

The analysis of maps, graphs, and tables reveals that the whole study area showed high rates of population growth, resulting in increased demand for infrastructure and urban services. However, the characteristics of the growth differed between the Canabrava community and its surroundings. While the community showed population growth in informal residential occupation, with poor living conditions in the largest part of the area, in the surrounding neighborhood areas the formal residential occupation evolved, almost entirely, through expansion of residential condominiums. This demonstrates the strong performance of real estate capital in the area and that this environment still has large areas of interest to the real estate and construction market.

In this context, if this trend of differential growth between the community and its surroundings is maintained in the coming years, there will be intensification of formal occupation in 
the surrounding area by residential condominiums and densification by informal occupations in the community. This trend has been reinforced by the influence of Paralela Av., which makes the area attractive for real estate expansion, and may lead to the accentuation of the gap between the conditions of infrastructure and urban services in the community and in its surroundings.

The use of census tract data allowed for the realization that extreme care is necessary in representing spatialized data. This is because many census tracts are extensive in their dimensions and have a shape that can lead to misinterpretations. For example, a specific area with a high demographic density may not be apparent if this area is inside a large census tract. This demonstrates how important it is to adjust the census tracts' limits, making the necessary adjustment calculations in its area and total population as well as in other data that may be needed for the research. The use of remote sensing images, which have a minimum spatial resolution that permits the identification of buildings, allows the adjustment of these limits and the calculation of averages that make improved spatialization of the data possible. The ideal is to use images and census tracts of the same year or, when that is impossible, years as close as possible, as was shown in this article.

The methodology adopted in this article, using remote sensing images and census data jointly, proved to be effective and therefore replicable in similar studies that seek to analyze the population dynamics of specific areas.

The importance of studies like this one is due, among other factors, to the fact that they enable the spatial representation of population dynamics in the inner urban space. This is an effective tool in the analysis of the city and its processes, on various scales, and contributes to the scientific discussion of urban processes so as to propose alternatives that seek to improve the quality of life in the urban environment. Therefore, more contributions can be added to research using census tract data and remote sensing in a larger time scale, in places with different characteristics within the same city, allowing for understanding of each place's dynamics and for proposing solutions to the problems encountered.

This study makes evident the need for the adoption of public policies that consider the spatial-temporal dynamic and the configuration of different occupation patterns of intra-urban spaces. Effective urban planning and urban intervention mechanisms should consider analyses of population growth, in a given interval of time, noting the peculiarities of different parts of the city, in order to estimate the degree of existing and increasing demand for infrastructure and urban services imposed by new residential condominiums, as in the case of Canabrava, so that this investment in infrastructure can extend to the neglected surrounding areas. With this, the 
government can and should seek to serve a population increase by providing improved quality of life in the existing urban environment and in the environment still in the process of development.

\section{REFERENCES}

ALMEIDA, C. M. de et al. O sensoriamento remoto como instrumental para o mapeamento da urbanização dispersa. In: Anais do 1 Seminário Internacional sobre Urbanização Dispersa e Mudanças no Tecido Urbano. São Paulo: FAUUSP, 2006. Available: < http://mtcm17.sid.inpe.br/col/sid.inpe.br/mtc-m17@80/2007/10.08.15.16/doc/Artigo_Livro_FAUUSP.PDF>. Accessed 28 June 2015.

CÂMARA, G. Geoprocessamento para Projetos Ambientais. São José dos Campos: INPE, 1996.

CONDER. Base Cartográfica SICAR/RMS: Município de Salvador anos 1976 e 1992 escalas 1:8.000 e 1:10.000 - Fotografias Aéreas Verticais. Salvador: CONDER/INFORMS, 1992.

GORDILHO-SOUZA, A. G. Limites do habitar: segregação e exclusão na configuração urbana contemporânea de Salvador e perspectivas no final do século XX. 2. ed. Salvador: EDUFBA, 2008. 496p.

IBGE. Banco de dados do Censo Demográfico de 1991. Available: <http://www.ibge.gov.br/home/estatistica/populacao/censodem/>. Accessed 09 January 2014.

IBGE. Banco de dados do Censo Demográfico de 2010. Available: <http://www.ibge.gov.br/home/estatistica/populacao/censo2010/caracteristicas_da_populacao/defau lt_caracteristicas_da_populacao.shtm>. Accessed 01 January 2014. 
JENSEN, J. R. Sensoriamento Remoto do Ambiente: Uma perspectiva em recursos terrestres. São José dos Campos, SP: Parêntese, 2009.

LEITE, M. E. et al. Monitoramento da dinâmica no uso do solo urbano de Montes Claros/MG por imagens de alta resolução espacial. In: Caminhos de Geografia (UFU), v. 15, p. 172-180, 2014. Available: <http://www.seer.ufu.br/index.php/caminhosdegeografia/article/viewFile/26366/15468>. Accessed 18 June 2015.

LOMBARDO, M. A. Aplicação das técnicas de sensoriamento remoto e sistemas de informações geográficas nos estudos urbanos. In: Revista do Departamento de Geografia (USP), São Paulo, v. 10, 1996. Available: <http://www.revistas.usp.br/rdg/article/viewFile/53700/57663>. Accessed 25 June 2015.

MARICATO, E. O impasse da política urbana no Brasil. Petrópolis: Vozes, 2011.

MARTINS, A. S.; LEITE, M. E. Análise do crescimento das favelas da cidade de Montes Claros MG por imagens de alta resolução espacial. In: Anais XVII Simpósio Brasileiro de Sensoriamento Remoto - SBSR. João Pessoa: INPE, 2015. p. 3715-3721. Available: <http://www.dsr.inpe.br/sbsr2015/files/p0730.pdf>. Accessed 20 June 2015.

MASCARÓ, J. L. Infra-estrutura urbana. Porto Alegre: Masquatro Editora, 2005. 207p.

NOVO, E. M. L. M. Sensoriamento Remoto: Princípios e Aplicações. São Paulo: Blucher, 2008.

PANGEA. Programa CATA-AÇÃO. Diretrizes para o desenvolvimento socioambiental do bairro de Canabrava. Salvador: PANGEA, 2010. 
ROSA, R. Introdução ao sensoriamento remoto. Uberlândia: UFU, 2007.

SANTOS, E.; PINHO, J. A. G. de; MORAES, L. R. S.; Fischer, T. (Org.). O Caminho das Águas em Salvador: Bacias Hidrográficas, Bairros e Fontes. Salvador: CIAGS/UFBA; SEMA, 2010. 486 p.

SOUZA, R. G. V. de. A expansão urbana da região metropolitana de Belo Horizonte e suas implicações para a redistribuição espacial da população: o caso do município de Nova Lima 1991/2000. 2005. 94 f. Dissertação (Mestrado) - Faculdade de Ciências Econômicas, Universidade Federal de Minas Gerais, Belo Horizonte, 2005.

VOLPE, L. L.; LOMBARDO, M. A. A análise do uso da terra no entorno do trecho oeste do Rodoanel Mario Covas na cidade de São Paulo por meio de técnicas de Sensoriamento Remoto. In: Revista do Departamento de Geografia, Universidade de São Paulo, v. 21, p. 23-43, 2011. Available: <http://www.revistas.usp.br/rdg/article/view/47229/50965>. Accessed 20 June 2015. 